\title{
The COVID-19 pandemic: biological evolution, treatment options and consequences
}

\author{
Sovik $\operatorname{Das}^{1}$ (1) $\cdot$ Swati $\operatorname{Das}^{2}$ (D) M. M. Ghangrekar ${ }^{1,2}$ (i)
}

Received: 10 May 2020 / Accepted: 19 June 2020 / Published online: 2 July 2020

(c) Springer Nature Switzerland AG 2020

\begin{abstract}
The spread of novel coronavirus SARS-CoV-2, the cause of the pandemic COVID-19 has emerged as a global matter of concern in the last couple of months. It has rapidly spread around the globe, which initially began in the city of Wuhan, People's Republic of China and is hypothesized to originate from the group of Rhinolophus bats. Till date, there has been no clinically proven vaccine against the SARS-CoV-2 and thus the doctors are employing the other well-known techniques, which have previously successfully tackled similar other human coronaviruses. To prevent the further spread of COVID-19, doctors are advising isolation of the infected patients, and also regular washing of hands and the use of face mask for the common people. In the wake of the COVID-19 outbreak, the countries are going for nationwide lockdown as the only preventive measure to avert community transmission of this disease, which is having economic, social and psychological effect on the general mass. Therefore, this comprehensive review article encapsulates the biological evolution of human coronaviruses, probable treatment and control strategies to combat COVID-19 and, its impact on human life.
\end{abstract}

Keywords Coronavirus $\cdot$ COVID-19 $\cdot$ Pandemic $\cdot$ Respiratory infection $\cdot$ SARS-CoV-2 $\cdot$ Treatment

\section{Introduction}

In the last week of December 2019, a patient infected with an undefined respiratory syndrome resembling viral pneumonia was admitted in Wuhan hospital, Wuhan, Hubei providence, People's Republic of China (PRC). Later on, from the sequenced-based characterization of lower respiratory tract samples isolated from the infected patients, the World Health Organization (WHO) announced that this viral disease is caused by a novel coronavirus and named the disease as COVID-19 [1]. The COVID-19, which has now emerged as a global pandemic, was reported to be first instigated from the seafood market where live animals like frogs, bats, snakes, snails, birds, pigs, cats and dogs are regularly wholesaled in Wuhan city of PRC [2]. After analysis of the genetic sequence of COVID-19 causing virus, it was decided that infected person might have visited the seafood market

Sovik Das

dassovik@iitkgp.ac.in

1 Department of Civil Engineering, Indian Institute of Technology, Kharagpur 721302, India

2 PK Sinha Centre for Bioenergy and Renewables, Indian Institute of Technology, Kharagpur 721302, India situated in the Wuhan City or might have consumed infected birds or animals. Conversely, further surveys exposed that few cases were also reported where individuals got infected even though they have not visited the seafood market of the Wuhan city. Owing to this investigation, it was confirmed that COVID-19 causing virus was competent for community transmission through human as a carrier and thus, rapidly spread over more than 200 countries in the globe [3]. This novel virus is transmitted from human to human due to the close contact with the infected person or due to the exposure to the respiratory droplets released during coughing and sneezing of an infected person. This type of respiratory droplets of the infected person can enter into the respiratory system of a healthy human through the mouth and nose during breathing [4].

In the past, a similar type of pandemic were noticed, however, due to a different group of coronaviruses named as Severe Acute Respiratory Syndrome coronavirus (SARS$\mathrm{CoV}$ ) centred on Guangdong province, PRC and the Middle East Respiratory Syndrome Coronavirus (MERS-CoV) in Arabian Peninsula. In 2003, SARS-CoV virus, a member of the beta-coronavirus, affected 8098 individuals with a mortality rate of $9.5 \%$ spread over 26 countries in the world [5]. In 2012, another pandemic causing coronavirus termed 
as MERS-CoV, a member of beta-coronavirus that varied from other human coronaviruses $(\mathrm{HCoV})$, was also reported to be spread all over the Saudi Arabian nations. The WHO confirmed that this group of MERS-CoV affected more than 2000 humans with a mortality rate of $34.5 \%$.

After analysis of COVID-19 syndrome, it was observed that the community transmission rate of SARS-CoV-2 is much higher as compared to the earlier SARS-CoV outbreak. Due to the high transmission rate of this coronavirus, the affected nations tried to control the spread of this deadly virus by isolating the probable carriers travelling from foreign countries. Moreover, other precautionary measures, like thermal scanning at the majority of the international airports and restrictions from organizing community gatherings, etc., were also enforced to tackle the situation [6]. Furthermore, almost all the affected nations are electing for nationwide lockdown to prevent the community transmission COVID-19. However, it is a tedious job to control the citizens employing the lockdown process for a longer period of time and therefore, the authorities should try to propagate awareness among people and educate them for correct personal hygienic practices to be adopted to fight against this pandemic.

The impact of the novel coronavirus and its symptoms, biological evolution, transmission mechanism and probable treatments and containment options are articulated briefly in this review article (Fig. 1). Furthermore, the environmental, economical, psychological and social impacts of this pandemic on human life especially in the India context are also discussed.

Probable secondary host
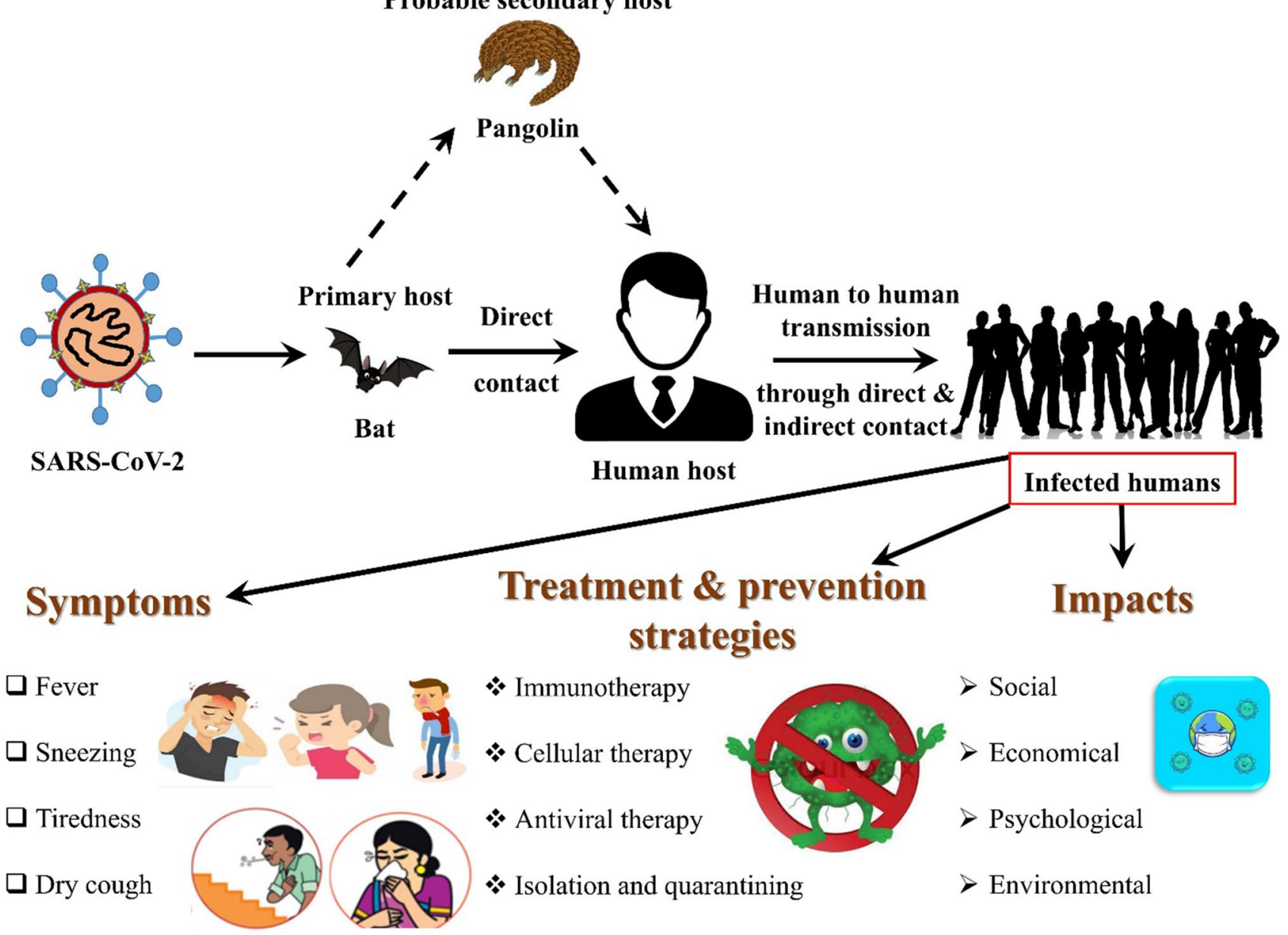

Shortness of breath

Persistent pain in the chest

Fig. 1 Graphical representation of areas focused on in the article 


\section{Origin and biological evolution}

For the development of preventive strategies like vaccines to combat COVID-19, the source of origin, biological mutation and the transmission rate of this virus needs to be evaluated judiciously. At the time of SARS pandemic in the year of 2003, the scientist recognized that the source of the virus was raccoon dogs and palm civets. After genetic sequencing of samples collected from palm civets, commonly sold in the seafood market, it was observed that palm civet might be a secondary host of SARS-CoV [7]. Thereafter, researchers also suggested that the group of Rhinolophus bats are competent to produce anti-SARS$\mathrm{CoV}$ antibodies, thus confirmed that this group of bats were the primary reservoir of the viral reproduction [8].

In 2012, another pandemic caused by MERS-CoV, the member of beta-coronavirus had spread worldwide and the researchers proposed that the camels are the zoonotic source of this virus [9]. However, many researchers suggested that the key host of this virus is Pipistrellus bat and probably they can transmit this virus to the humans [10]. Furthermore, genomic similarities were found between SARS-CoV-2 and SARS-like bat viruses, thus exemplifying bats as the probably the primary host of novel SARS-CoV-2 [11]. From the further structural analysis of receptor binding spike glycoprotein, an essential protein responsible for transmitting the virus into human immune cells, it was suggested that novel COVID-19 causing virus has mutated from SARS-CoV [11]. Recently, researchers discovered that anteater animals named pangolins are the probable intermediate host for the transmission of novel SARS-CoV-2 between bats to the humans [12]. However, to exterminate this pandemic, more research efforts are essential to find out the intermediate zoonotic source of COVID-19 and especially its epidemiological features that instigated the viral transmission to the human host, for the effective control, treatment and prevention from the spreading of this lethal virus.

\section{Structure of SARS-CoV-2}

The pandemic causing SARS-CoV-2 is a member of the beta-coronavirus family, which originated from bats or pangolins and resemble with previously reported other two epidemic causing coronaviruses, namely SARS-CoV and MERS-CoV [12]. According to Hui et al. there are seven different novel strains of HCoVs named as 229E and NL63 strains from the family of alpha-coronaviruses, and OC43, HKU1, SARS, MERS, and SARS-CoV-2 strain from the family of beta-coronaviruses present all over the world [13]. Among these strains, SARS-CoV and MERS-CoV strain of $\mathrm{HCoV}$ are extensively well-known coronaviruses as each strain has led to a global pandemic. According to WHO, the mortality rate of SARS-CoV-2 is lesser; however, the transmission rate is much higher than SARS-CoV [14].

The novel COVID-19 causing virus has thirty thousand long base pair single-stranded ribonucleic acid (RNA) with a diameter of 80-120 nm [15]. Moreover, the virus also contains two important groups of proteins, namely the fundamental proteins (spike, nucleocapsid, matrix and envelope) and the non-fundamental proteases proteins (nsp3 and nsp5), and RNA-dependent RNA polymerase proteins (nsp12) that distinguish all the groups of coronaviruses (Fig. 2) [16]. Among total proteins of SARS-CoV-2, the unique viral spike proteins present in homo-trimetric state on the outer surface of virion has the ability to infect the target cell through a viral attachment process [17]. Moreover, researchers also explained that the novel SARS-CoV-2 virus has a specific peptide named PrrA that can cleave viral spike protein using cellular proteases enzyme and thus, the viral protein can be easily transmitted from the virus to host cell [18].

\section{Epidemiologic and pathogenic characteristics of SARS-CoV-2}

The seventh member of the $\mathrm{HCoV}$, formally known as SARS-CoV-2 has the proficiency to infect the human respiratory tract, whereas other two pandemic causing viruses such as SARS-CoV and the MERS-CoV are accountable for pneumonia and common cold (Table 1). The reasons for these infections instigated by MERS-CoV and SARS-CoV are due to the existence of two different type of receptors, named as dipeptidyl peptidase 4 (DPP4) and angiotensinconverting enzyme 2 (ACE2), respectively [19]. These human receptors are responsible for receiving the viral transmission into the human cell (Fig. 3). After analysis of the genomic categorization of SARS-CoV-2, it was observed that their genomic sequences were much similar (almost $70 \%$ ) to the SARS-CoV and both of them infects the same human receptor named as ACE2 [20]. On the other hand, the specific spike proteins of SARS-CoV-2 virus can bind to human ACE2 receptor protein with higher affinity (almost 10 to 20 times more) compared to the SARS-CoV viral spike bonding [20]. Therefore, the transmission rate of SARSCoV-2 is much higher and it is the main reason behind it spreading globally within a shorter period of time, which was not the case for other $\mathrm{HCoV}$.

When SARS-CoV-2 enters into the alveolar epithelial cell of the human respiratory tract, the virus triggers human immune response owing to the rapid cell multiplication rate of SARS-CoV-2. Next, the pulmonary tissue present in the human respiratory tract gets damaged by eliciting the activation of more white blood cells, which 
Fig. 2 The structure of the novel SARS-CoV-2

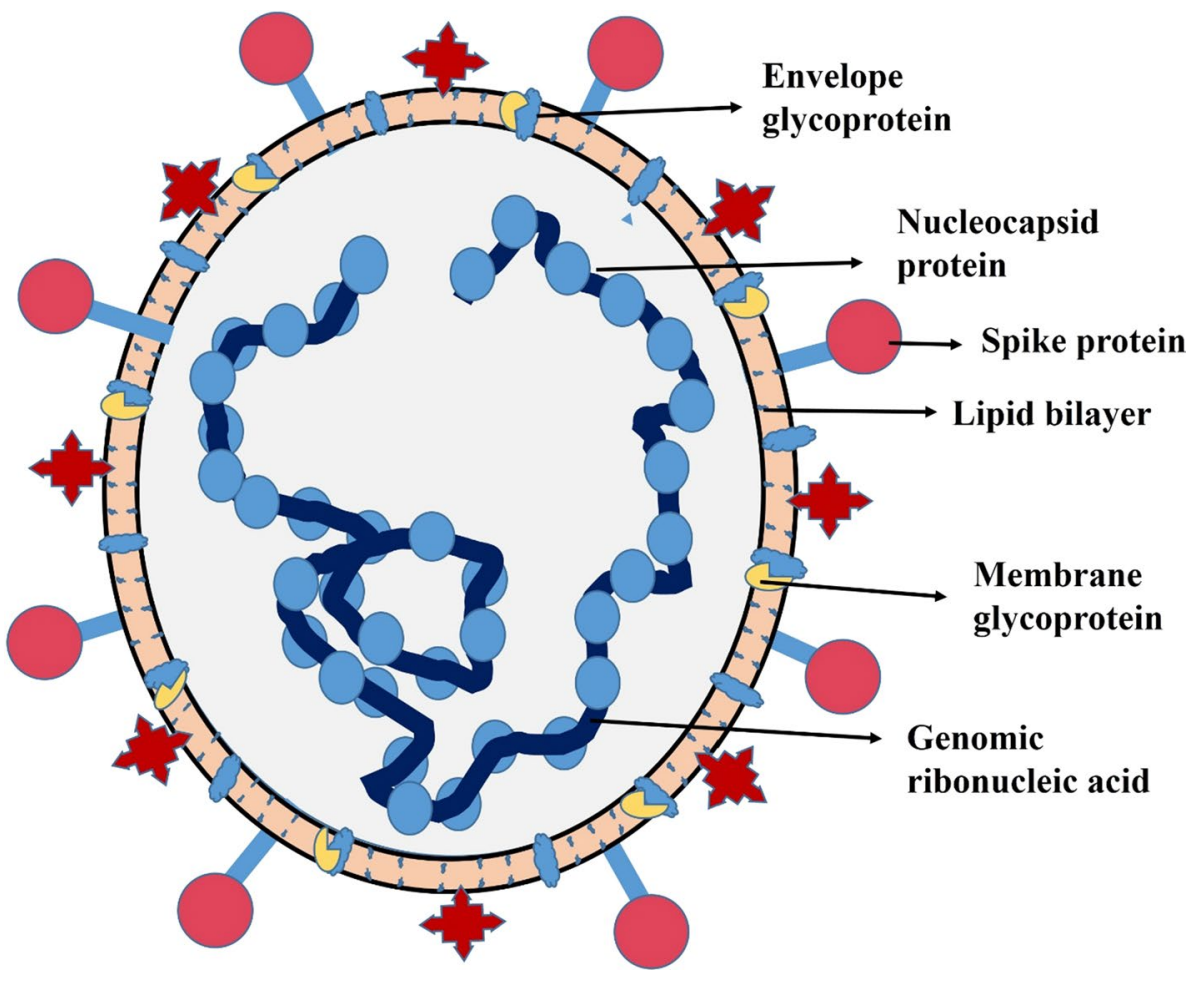

Table 1 Pathological and epidemiological characteristics of epidemic causing viruses all over the world

\begin{tabular}{lllllll}
\hline Virus name & Primary reservoir & Intermediate host & Name of the receptor protein & $\begin{array}{l}\text { Repro- } \\
\text { ductive } \\
\text { number }\end{array}$ & $\begin{array}{c}\text { Mortality rate } \\
\text { References }\end{array}$ \\
\hline SARS-CoV (2003) & Rhinolophus bats & Palm civets & Antigiotensin converting enzyme 2 & $1.7-1.9$ & $9.5 \%$ & {$[26]$} \\
MERS-CoV (2012) & Pipistrellus bats & Camels & Dipeptidyal peptidase 4 & $<1$ & $34.5 \%$ & {$[27]$} \\
SARS-CoV-2 (2019) & Bats & Probably pangolins & Antigiotensin converting enzyme 2 & $2-2.5$ & $6 \%$ till date & {$[26]$} \\
\hline
\end{tabular}

is commonly known as cytokine release syndrome [21]. Cytokine release syndrome or hypercytokinemia is a form of systemic inflammatory response syndrome when a large number of human white blood cells are activated and uncontrollably release inflammatory cytokines and cause severe lung condition commonly known as acute respiratory distress syndrome (ARDS) [22]. This ARDS can prevent the organs from receiving oxygen required for their proper functioning and eventually causing multiple organ failure [23].

During the analysis of the first 99 confirmed cases of patients infected with SARS-CoV-2, cytokine release syndrome was noticed for patients with severe COVID-19 symptoms; whereas 17 patients were diagnosed with ARDS and among them, the condition of 11 patients deteriorated within a short period of time and eventually, they died due to multiple organ failure [24]. Moreover, due to the infection of COVID-19, the total number of lymphocyte cells reduces and the functionally of these lymphocyte cells get exhausted which also affects the immune system and therefore, causing respiratory organ failure [25].

\section{Transmission path over the susceptible population}

The novel SARS-CoV-2 transmitted rapidly all over the world in the matter of a few weeks. The transmission path of this virus from human to human is through close contact leading to the contact with the slimy layer saliva of the mouth, tears of eyes or respiratory droplets of running nose [28]. Furthermore, a closed environment with continuous exposure to high concentrated aerosol is also a route of COVID-19 transmission [29]. Furthermore, researchers demonstrated that COVID-19 infected person has several intestinal infections like diarrhoea, vomiting, queasiness to name a few [30]. According to Zhang et al. the human respiratory tract is not the only potential route for entry of SARS-CoV-2 into the human host, the digestive tract is also one of the probable sources of the infection as the 




\section{Host human cell}

Fig. 3 The life cycle of novel SARS-CoV-2 and its interaction with human host cell

COVID-19 symptoms are allied with the alveolar epithelial cells of the lungs and enterocytes or intestinal absorptive cells of the human small intestine [31]. Recently, scientists also inspected the transmission of this virus through the breast milk of a mother to a newborn baby. However, more investigations are required in this field to determine promising preventive strategies to counter COVID-19.

\section{Impact on human health}

\section{Clinical symptoms and detection of COVID-19 disease}

In the beginning, for a COVID-19 patient, the clinical symptoms are weakness, nasal blocking, sneezing, headache, painful throat, vomiting, nausea and diarrhoea. After five to six days, the infected patients tend to have a high fever with muscle pain, dry cough, and ultimately leading to dyspnoea or hypoxaemia. During this stage, most of the pulmonary tissue of the human respiratory tract and the immune system is majorly affected. However, some asymptomatic cases were also observed where the patients did not exhibit any acute COVID-19 symptoms. Sometimes they also tend to have a mild fever or even no fever, low fatigue and no respiratory problems. However, these asymptomatic patients can be carriers, who are responsible for the transmission of the SARS-CoV-2 into other human body [32].

The fast and precise recognition of COVID-19 is crucial for us to control this pandemic. In the laboratory, genomic sequencing process using reverse transcription-quantitative polymerase chain reaction (RT-qPCR) is an accurate detection process for this virus. The viral genome is characterized using stool, saliva or blood sample collected from suspected patients [33]. Later on, Kelvin et al. reported that the detection of SARS-CoV-2 was successfully investigated in the sputum specimens of sick patients using RT-qPCR [34]. However, there is a major risk for the transmission of this viral infection from infected patients to healthcare workers, if proper protective measures are not being taken during the collection of saliva specimen from an infected person for testing. Thus, appropriate precautionary measures are necessary to avoid further contamination during the viral detection test procedure.

\section{Probable treatment process and prevention}

The novel COVID-19 pandemic causative SARS-CoV-2 virus has spread over more than 200 countries and has affected 7,682,831 people, among them 426,426 persons have died and 3,650,044 persons have successfully recovered from this disease as on 13th June 2020, as per the data 
provided by the John Hopkins Coronavirus Resource Centre. Suspected and confirmed cases of COVID-19 should be treated in designated hospitals or nursing homes well acquainted with protective isolation and quarantine measures. Also, critical patients should be admitted immediately to the intensive care unit.

Currently, numerous comparative experiments and clinical trials have been carried on for investigating the efficacy and safety of several antiviral drugs for the treatment of COVID-19 pandemic. Furthermore, several therapeutic and prophylactic strategies have also been advocated for the treatment of patients infected with SARS-CoV-2. As an example, the sequence-specific double-stranded RNAs have therapeutic potential to suppress the viral genomic expression through an endogenous cellular process named as RNA interference. After genomic analysis, it was also reported that RNA interference can be used in the treatment of viral causative infectious diseases, such as human immunodeficiency virus (HIV) and hepatitis. Similarly, Chang et al. reported that small interfering RNAs (siRNAs) can inhibit SARS-CoV infection in monkeys (Rhesus macaques) without any side effects [35].

\section{Standard treatments}

The common control strategies for the prevention against COVID-19 is complete isolation of the infected patient with his face being covered with a protective N95 or FFP3 mask, sterilized gown and regular monitoring of the body temperature, blood pressure, heart rate, pulse, sputum screening, respiratory rate and other prominent symptoms. Some of the other treatment therapeutic and prophylactic strategies used to treat the patients infected with SARS-CoV-2 are discussed in the following subsections.

\section{Antiviral therapy}

In several COVID-19 cases, interferon- $\alpha$ (IFN- $\alpha$ ) acts as a suitable drug due to its resistivity against this viral infection. When the infected patients are dosed with IFN- $\alpha$, the replication of the SARS-CoV viral genome is defeated by stimulating both innate and adaptive immune responses [36]. Researchers have shown the successful outcome of IFN- $\alpha$ drug on SARS-CoV infected cynomolgus monkey [37]. Likewise in a pilot clinical trial, the healing mechanism of synthetic recombinant IFN- $\alpha$ for people infected with SARS was also exhibited [38]. Therefore, further trials on IFN- $\alpha$ shall be made so as to be recommended to cure COVID-19 patients, if trials are successful.

Lopinavir and ritonavir, the protease inhibitor drugs also has the ability to affect the reproduction of HIV by generating antibody in the human body [39]. Generally, ritonavir and lopinavir drugs can defeat the protein synthesis process of the COVID-19 causative virus by binding the protease (endopeptidase C30) present in the SARS-CoV-2 [40]. However, more research is required to apply this drug to tackle COVID-19 outspread.

Chloroquine drug is broadly applied for autoimmune diseases and patients suffering from malaria [41]. Recently, chloroquine has been recommended as a potential antiviral drug as it can prevent the SARS-CoV-2 infection by enhancing endosomal $\mathrm{pH}$ required for fusion of most viral protein [42]. According to Wang et al. the cheap drug chloroquine has been successfully tested in vitro process against the recently appeared COVID-19 disease [43]. Therefore, chloroquine could be considered as a prospective antiviral drug for the treatment of COVID-19.

Hydroxychloroquine an analogue of chloroquine is also a well-known drug which is employed for the treatment of malaria. In 2003 during the SARS epidemic, hydroxychloroquine was considered as an antiviral drug for the treatment of patients infected with SARS-CoV disease [44]. According to the physiologically based pharmacokinetic models, Yao et al. reported that hydroxychloroquine drug was adequately strong against SARS-CoV-2 infected patient compared to chloroquine [45]. Hence, both antimalarial drug, namely chloroquine and hydroxychloroquine, can be used to treat patients infected with SARS-CoV-2.

Arbidol also has the potential to suppress the influenza viral infection. Furthermore, arbidol and arbidol mesylate were considered as an antiviral drug against SARS epidemic by inhibiting the genomic replications of SARS-CoV using an in vitro assay [46]. Moreover, several case series exhibited that arbidol and arbidol analogous drugs should be recommended for the treatment of COVID-19 pneumonia [43]. Therefore, these antiviral drugs can be the source of promising remedial measures to prevent the COVID-19 outbreak. Additionally, other numerous antiviral drugs were also tested to determine its efficacy to compete against this pandemic (Table 2). However, more research and clinical trials, for both in vivo and in vitro conditions, are required for elucidating the treatment efficacy of newly recommended drugs or vaccines, which is to be applied against COVID-19.

\section{Cellular therapy to defence against COVID-19}

Human natural killer (NK) cells have significant autoimmune response proficient to prevent viral infection or fight with other malignant cells. Human NK cells can disrupt the viral cell by the antibody-dependent cellular cytotoxicity process [53]. In this manner, all virus-infected cells are lysed through NK cells. Furthermore, many researchers reported that NK cells have the antiviral activity against SARSCoV, HIV and herpes simplex virus type 1 (HSV-1) [54]. Moreover, it was reported that umbilical cord blood-derived NK cells have the capability to treat the recent COVID-19 
Table 2 Probable antiviral drugs for the treatment of newly emerged COVID-19 causing pneumonia

\begin{tabular}{|c|c|c|c|}
\hline Antiviral drugs & Prevention & Treatment and diagnosis & References \\
\hline Remdesivir & $\begin{array}{l}\text { Successfully prevents the SARS-CoV, MERS- } \\
\text { CoV in vivo and Ebola virus }\end{array}$ & $\begin{array}{l}\text { Effectively inhibits the genomic replication } \\
\text { of SARS-CoV-2 virus at low-micromolar } \\
\text { concentration }\end{array}$ & [47] \\
\hline Emtricitabine and Tenofovir & $\begin{array}{l}\text { HIV infection and currently being trialed for } \\
\text { COVID-19 }\end{array}$ & $\begin{array}{l}\text { Disrupts the nucleoside and non-nucleoside } \\
\text { reverse transcriptase of the viral protein }\end{array}$ & [48] \\
\hline Azvudine & Clinical trial for stage 3 COVID-19 pneumonia & $\begin{array}{l}\text { Decreases the viral nucleic acid reproduction } \\
\text { rate of SARS-CoV-2 }\end{array}$ & [49] \\
\hline Corticosteroids & $\begin{array}{l}\text { Prevent SARS-CoV, MERS-CoV and clinical } \\
\text { trial for SARS-CoV-2 }\end{array}$ & Suppresses lung inflammation & {$[50]$} \\
\hline Abidol hydrochloride & $\begin{array}{l}\text { Broad spectrum inhibitor for influenza A and } \\
\text { B virus, clinical study on COVID-19 }\end{array}$ & $\begin{array}{l}\text { Non-nucleoside widely used antiviral drug } \\
\text { with immune enhancing effect }\end{array}$ & {$[51]$} \\
\hline Baicalin, Chinese herbal medicine & Antiviral activity against SARS-CoV & $\begin{array}{l}\text { Inhibit the entry of SARS-CoV virus into host } \\
\text { cells }\end{array}$ & {$[52]$} \\
\hline
\end{tabular}

disease [55]. Thus, these type of NK cells can be considered as an efficient cellular therapeutic option for the treatment of the newly emerged COVID-19 infection.

Natural cellular therapy employing mesenchymal stem cells (MSCs), one of the robust anti-inflammatory active cell, can also be a potential alternative to treat patients infected with SARS-CoV-2 [56]. Human blood and placenta of the umbilical cord are promising sources of the MSCs. Moreover, several researchers reported that MSCs have the capability to ameliorate chronic lung grievance, diminish lung fibrosis and improve acute respiratory problems by stimulating several repair processes against virus-infected tissues [57]. Furthermore, MSCs can also prevent cytokine stress syndromes, ARDS and acute lung infected injury and thus diminish the mortality rate of COVID-19. Therefore, MSCs can be used for therapeutic trial on COVID-19 causative pneumonia.

\section{Immunotherapy}

Convalescent plasma can produce several types of immunoglobulin (Ig) antibodies like IgG, IgA, IgM, IgE, and IgD in the body of recovered patients. These types of antiviral antibodies have the ability to treat innumerable contagious maladies such as influenza A (H5N1), poliomyelitis, and Ebola [58]. Recently, in Taiwan and Hong Kong, few COVID-19 patients were treated by applying convalescent plasma collected from people recovered from SARS-CoV infection. After $24 \mathrm{~h}$ of plasma transfusion, partial passive immunization was observed among the COVID-19 patients, and plasma viral load of the infected patient was also diminished (almost 105 copies/mL to untraceable levels) [59]. Therefore, convalescent plasma therapy could also be a potential therapeutic candidate for the prevention of COVID-19.

The retardation of the COVID-19 pandemic might be governed by the development of human monoclonal antibodies against viral infection. Several researchers reported that monoclonal antibodies adversely affect the spike protein of $\mathrm{HCoV}$ and thus prevents the entry of viral nucleic acid into host cells [60]. Monoclonal antibodies can directly target the receptor-binding domain (RBD) of 193-amino acid fragments in viral spike protein and defuse the viral infection [61]. The COVID-19 viral genomic replication deactivating monoclonal antibodies named as a CR3014 and CR3022 were also reported to target SARS-CoV RBD monopolistically and synergistically neutralized the virus [62]. Therefore, CR3014 and CR3022 alone or amalgamation of these two antibodies with other neutralizing monoclonal antibodies could be a potential treatment option for the patients infected with SARS-CoV-2. However, more research, therapeutic strategies and clinical trials should be accomplished and their safety and efficacy also needs to be determined while developing novel drugs, new and innovative vaccines to enhance the immunity, which would aid to confront the newly emerged SARS-CoV-2.

\section{Other prevention and control strategies}

Currently, there is no particular drug for the treatment of COVID-19, several prevention strategies are immediately required to reduce the transmission rate of the SARS-CoV-2. Furthermore, more control strategies are required to focus on the viral reproduction number $\left(R_{0}\right)$ as the level of any pandemic will rapidly enhance when $R_{0}$ is greater than 1 . Therefore, control processes must focus on reducing the value of $R_{0}$ to less than 1 . According to $\mathrm{WHO}$, prevention strategy like strict avoidance of close contact with patients suffering from respiratory problems or having cold and avoiding unprotected contact with wild animals should be adopted. Moreover, the use of masks is advisable to prevent the droplets, cough, and sneezes from an infected person to transmit to other healthy persons. Additionally, frequent hand 
washing after contact with suspected persons, maintaining at least two meter distance from other person and use individual quarantine place for each and every suspected person should be fruitful solution for the control of this infection from spreading.

Furthermore, several institutes around the globe have developed innumerable innovative strategies, such as lowcost portable ventilators, robotic drones for sanitization, various mobile applications for contact tracing, robots for delivery of food and medicines and ultraviolet technology fitted in a trunk for sanitizing electronic gadgets, grocery items and currency, which can assist in combating the perilous COVID-19 pandemic. Furthermore, infection proof cloths for the usage in hospital, cost-effective testing kits, isolation pods for COVID-19 infected patients, bubble helmets instead of traditional oxygen masks were also some of the innovative prevention strategies that have been used worldwide since the COVID-19 outbreak. Sulfated polysaccharides extracted from marine red alga Porphyridium sp. can also be envisioned as a coating material on the sanitary items for the prevention of COVID-19 [63]. Previously, researchers have also demonstrated the use of biochar in as a building materials, which could reduce the breeding of mosquitoes the carriers of malaria, thus diminishing the transmission rate of malaria [64]. The most important strategy for countries with higher population density must be to use portable hand sanitizer or alcoholic sanitizer and should avoid body contacts with utilities and individuals. Also, doctors, nurses and other healthcare workers should wear hand gloves, protective N95 or FFP3 masks, air preventive gowns and other personal protective equipment to prevent the transmission of this virus.

\section{Effects of COVID-19 pandemic with a special focus on India}

The pandemic COVID-19 has affected almost all the countries in the world, which also includes India. The spread of the virus in India at a larger scale was reported in the beginning of March 2020; whereas, many European countries were already suffering from this lethal virus from early February 2020. Therefore, the widespread effect of this pandemic on India will be pronounced a little later than the other affected countries. This pandemic will have an enormous effect on the life of every Indian citizen especially on the lower middle and lower income people. These two classes of people majorly include labours, small shopkeepers and other people working in private and unorganized sectors. To counter the spread of this pandemic, India was required to enforce a nationwide lockdown, however, experts advised a longer period of lockdown to tackle the COVID-19 outbreak due to high population density in India [65]. Due to this preventive measure of lockdown, innumerable social and economical activities will be stalled, thus adversely affecting the life of common people including their livelihood.

The most important personal preventive measure for COVID-19 as suggested by the doctors is to wash hands frequently with soaps, hand washes and sanitizers. This has led to the higher consumption of water throughout India, which is again a major problem for a country like India, where ample amount of purified water is not available to all the citizens. Moreover, due to the increased rate of handwashing, the concentration of surfactants and xenobiotic compounds commonly present in hand washes, sanitizers and soaps will also increase in sewage, posing additional challenges for treatment [66]. The traditional treatment technologies installed at various treatment plants in India are not designed to treat or remove xenobiotics and surfactants even at lower concentrations [67]. Therefore, these treated sewage containing xenobiotics will be discharged into various water bodies and over a period of time, the concentration of these toxic compounds, which are both carcinogenic and endocrine disruptors, will increase in surface and groundwater [68]. Therefore, appropriate care should be taken while consuming surface and groundwater after this period of COVID-19 outbreak.

Infected and carriers of SARS-CoV-2 can excrete these viruses through their excretion system and ultimately this viruses ends up in sewage treatment plants [69]. The sewage can carry SARS-CoV-2 through the sewers laid below the roads and buildings and any leakage in these pipes could have risk of exposure of the population to this dangerous virus. Moreover, the reactors and other appurtenances of the sewage treatment plants can also get contaminated with these viruses; therefore, the operators and workers working in the sewage treatment plants also possess the risk of getting infected through this virus. Coronaviruses can remain viable in wastewater for up to 4 days and therefore, the workers at sewage treatment plants should use proper protective equipment while handling sewage and other apparatus/ equipment, which are exposed to the sewage [70]. Also, the equipment needs to be disinfected after every shift so that infected workers working in one shift does not transmit the disease to any other co-workers.

The sewage generated from quarantine centres and containment zones also needs to be carefully handled to curtail the spread of COVID-19. The sewage from these hotspots possesses high risk of spreading the perilous disease and therefore special care should be taken to handle it separately from wastewater generated from other sources [71]. Also, this sewage collected from hotspots needs to be treated separately, away from human settlements and sources of drinking water; thus, negating the chances of any possible contamination of virus even through the aerosols likely to be generate at treatment plant. Additional disinfection should also be 
provided before disposing of such a treated sewage and disposing it into sewers can be plausible technique to alleviate this problem.

Furthermore, sewage can also be an imperative parameter to gauge the spread of COVID-19 in a community, as it is difficult and uneconomical to test everyone in a community for SARS-CoV-2 infection. The genetic material, the viral RNA, can be extracted from sewage and tested to gauge the possibility of infected persons in the community from where the sewage is being collected [70]. Also, the regular monitoring of viral RNA present in sewage can signal a sudden peak in active cases without rigorous testing. This could provide the authorities with a major advantage of flattening the curve associated with the COVID-19 cases.

Though the mortality rate of COVID-19 is not on a higher side; however, due to the extensive spread of the infection among the masses, the number of fatalities will be very high and which is rising day by day. These dead bodies and other biomedical wastes generated from hospitals and nursing homes need to be managed scientifically. It would be ideal to dig mass graves and bury these dead bodies deep within the earth without handing it over to the family members. However, due to the numerous social stigma prevalent in the Indian society, this option may not be always viable. If these bodies are indeed handed over to the family members then these dead bodies should be sealed in leak-proof and hermetically sealed bags designed to carry biomedical wastes. Proper care should be taken to prevent any bodily fluid from leaving the sealed bags, which could again contaminate other healthy members of the family and relatives.

The medical apparatus like syringes, vials, etc., should also be safely taken away from the residential areas and incineration is recommended before the disposal of this biomedical waste, especially during the outbreak of a pandemic. Mask and other personal protective equipment used by the healthcare workers and doctors should also be disposed of appropriately so that the infection does not spread to other healthy persons through this equipment. As per the investigation carried out by van Doremalen et al. SARS-CoV-2 can be present in a viable form on plastic and stainless steels surfaces for more than $72 \mathrm{~h}$ and thus the need to dispose of biomedical waste scientifically can be envisioned [72]. India is a densely populated country and the availability of land away from the residential area for the digging of mass graves can thus be a major concern. However, efforts should be made to locate barren and infertile land preferably away from the city and in the outskirts, where barricades should be placed to prevent the entry of humans and also animals who can tamper these graves. Burning dead bodies of persons dying from COVID-19 can also be an options to disposal of these bodies, which otherwise possesses the risk of bio-hazards. However, burning of such huge number of bodies can have an adverse effect on the environment due to the emission of smoke and also ashes arising due to this burnings needs to be disposed safely.

The only well tested preventive measure to tackle this pandemic is social distancing, which can only be exemplified by enforcing lockdown. Due to this lockdown, all forms of public transports are temporarily stopped leading to the stoppage of numerous small scale businesses. Government and private sectors are also affected by this lockdown as the majority of the sectors are advising employees to work from home. Employees working in the sector of information technology can work from home; however, all other fields of work need physical involvement and thus these jobs are stopped due to the COVID-19 outbreak. Therefore, this will lead to an inferior revenue generation, which will have an adverse effect on the monthly remuneration of the employees. To compensate these economical losses few firms can take the easier route of mass sacking, which could be very hard on the common man bearing in mind the present scenario [73]. Furthermore, for the freshers looking for jobs in the upcoming placement months will also have to fight harder to secure a job as firms will try to minimize these economical losses by reducing the number of recruitments. However, the government of India is proactive in this situation and is aiding these firms with numerous financial plans and schemes to overcome this economical loss.

The daily wage labours with negligible savings are more gravely struck by the outbreak. Due to the lockdown, all construction-related works are at a standstill and these labours are majorly unemployed, which makes it difficult for them to feed their family members. In this regard, the government of India has also acted proactively by availing rations for these weaker sections of the society. The nationwide economic setback also had psychological repercussions on the citizens. They are uncertain of their next months' salary and also their job, which could lead to mental stress. Also, the fear of death within the patients infected with COVID-19 has led to the buildup of psychological anxiety translating into suicides [74]. For the younger generation like school and college goers, this lockdown has been very critical. Some of the educational institutes are opting to teach the students through online video lectures, while others have cancelled the classes due to the lockdown. Online lectures cannot effectively substitute class lectures; however, for the time being, it can be a suitable solution to continue teaching in the wake of the COVID-19 outbreak [75].

The COVID-19 outbreak has adversely affected the human life form in all the anticipated ways. However due to lockdown, the majority of the masses are confined in houses and thus cars and other automobiles commuting on the roads have reduced drastically. Therefore, noise and air pollution levels arising from these activities have also reduced considerably leading to a cleaner environment. Atmospheric air at many places have become better and less values of air quality 
index has been reported due to the lockdown [76]. This selfhealing of the environment due to reduced human activities can be a finger in the eyes of most developed race, i.e. the Homo sapiens to not to take the mother nature for granted and respect the rules of the environment. Furthermore, we should opt for more sustainable development options, where both nature and humans can coexist synergistically without venturing too much into someone else territory.

\section{Conclusion}

The global outbreak of COVID-19 has called for numerous precautionary measures and more steps are required to be taken to tackle the current situation, given that there is currently no proven vaccine available against the novel SARSCoV-2. Researchers are dedicatedly trying their level best to come up with the best possible way to fight this lethal virus and therefore, many drugs and therapeutic options, which were successful in tackling other diseases, have been suggested as possible measures to treat the patients infected with SARS-CoV-2. Furthermore, the effect of global COVID-19 outbreak is pronounced having both widespread social and economical repercussions on human life form. However, the general mass should follow the instructions given by the government, doctors and healthcare workers, which will help us in emerging victorious against COVID-19.

Authors' contributions SD-Conceptualization; Visualization; Data curation; Methodology; Formal analysis; Investigation; Writing-original draft; Software support. SD-Methodology; Validation; Formal analysis; Writing-original draft; Writing-review and editing. MMGResources; Funding acquisition; Supervision; Project administration

Funding The fellowship received for the second author from the Ministry of New and Renewable Energy, Government of India (IIT/SRIC/R/ $\mathrm{REF} / 2018 / 101$ ) is duly acknowledged. This work was also financially supported by The Ministry of Human Resource Development, Government of India (SAP17_IITKGP_05).

Availability of data and material The datasets used and/or analysed during the current study are available from the corresponding author on reasonable request.

\section{Compliance with ethical standards}

Conflict of interest The authors declare no conflict of interest.

\section{References}

1. Huang C, Wang Y, Li X, Ren L, Zhao J, Hu Y, Zhang L, Fan G, Xu J, Gu X (2020) Clinical features of patients infected with 2019 novel coronavirus in Wuhan, China. Lancet 395:497-506. https:// doi.org/10.1016/S0140-6736(20)30183-5
2. Wang C, Horby PW, Hayden FG, Gao GF (2020) A novel coronavirus outbreak of global health concern. Lancet 395:470-473. https://doi.org/10.1016/S0140-6736(20)30185-9

3. Han Q, Lin Q, Jin S, You L (2020) Coronavirus 2019-nCoV: a brief perspective from the front line. J Infect 80:373-377. https:// doi.org/10.1016/j.jinf.2020.02.010

4. Li Q, Guan X, Wu P, Wang X, Zhou L, Tong Y, Ren R, Leung KS, Lau EH, Wong JY (2020) Early transmission dynamics in Wuhan, China, of novel coronavirus-infected pneumonia. N Engl J Med. https://doi.org/10.1056/NEJMoa2001316

5. Peiris J, Guan Y, Yuen K (2004) Severe acute respiratory syndrome. Nat Med 10:S88-S97. https://doi.org/10.1038/nm1143

6. Krishnakumar B, Rana S (2020) COVID 19 in INDIA: strategies to combat from combination threat of life and livelihood. J Microbiol Immunol Infect. https://doi.org/10.1016/j.jmii.2020.03.024

7. Kan B, Wang M, Jing H, Xu H, Jiang X, Yan M, Liang W, Zheng H, Wan K, Liu Q (2005) Molecular evolution analysis and geographic investigation of severe acute respiratory syndrome coronavirus-like virus in palm civets at an animal market and on farms. J Virol 79:11892-11900. https://doi.org/10.1128/JVI.79.18.11892 $-11900.2005$

8. Shi Z, Hu Z (2008) A review of studies on animal reservoirs of the SARS coronavirus. Virus Res 133:74-87. https://doi. org/10.1016/j.virusres.2007.03.012

9. Paden C, Yusof M, Al Hammadi Z, Queen K, Tao Y, Eltahir Y, Elsayed E, Marzoug B, Bensalah O, Khalafalla A (2018) Zoonotic origin and transmission of Middle East respiratory syndrome coronavirus in the UAE. Zoonoses Public Health 65:322-333. https ://doi.org/10.1111/zph.12435

10. Huynh J, Li S, Yount B, Smith A, Sturges L, Olsen JC, Nagel J, Johnson JB, Agnihothram S, Gates JE (2012) Evidence supporting a zoonotic origin of human coronavirus strain NL63. J Virol 86:12816-12825. https://doi.org/10.1128/JVI.00906-12

11. Chan JF-W, Kok K-H, Zhu Z, Chu H, To KK-W, Yuan S, Yuen K-Y (2020) Genomic characterization of the 2019 novel humanpathogenic coronavirus isolated from a patient with atypical pneumonia after visiting Wuhan. Emerg Microbes Infect 9:221-236. https://doi.org/10.1080/22221751.2020.1719902

12. Zhang C, Zheng W, Huang X, Bell EW, Zhou X, Zhang Y (2020) Protein structure and sequence re-analysis of 2019-nCoV genome does not indicate snakes as its intermediate host or the unique similarity between its spike protein insertions and HIV-1. arXiv preprint. https://doi.org/10.1021/acs.jproteome.0c00129

13. Hui DS, Azhar E, Madani TA, Ntoumi F, Kock R, Dar O, Ippolito G, Mchugh TD, Memish ZA, Drosten C (2020) The continuing 2019-nCoV epidemic threat of novel coronaviruses to global health-the latest 2019 novel coronavirus outbreak in Wuhan, China. Int J Infect Dis 91:264-266. https://doi.org/10.1016/j. ijid.2020.01.009

14. Hemida MG, Alnaeem A (2019) Some One Health based control strategies for the Middle East respiratory syndrome coronavirus. One Health. https://doi.org/10.1016/j.onehlt.2019.100102

15. Chan JF-W, To KK-W, Tse H, Jin D-Y, Yuen K-Y (2013) Interspecies transmission and emergence of novel viruses: lessons from bats and birds. Trends Microbiol 21:544-555. https://doi. org/10.1016/j.tim.2013.05.005

16. Elfiky AA, Mahdy SM, Elshemey WM (2017) Quantitative structure-activity relationship and molecular docking revealed a potency of anti-hepatitis $\mathrm{C}$ virus drugs against human corona viruses. J Med Virol 89:1040-1047. https://doi.org/10.1002/ jmv.24736

17. Ibrahim IM, Abdelmalek DH, Elfiky AA (2019) GRP78: a cell's response to stress. Life Sci. https://doi.org/10.1016/j. Ifs. 2019.04 .022

18. Li X, Zai J, Zhao Q, Nie Q, Li Y, Foley BT, Chaillon A (2020) Evolutionary history, potential intermediate animal host, and 
cross-species analyses of SARS-CoV-2. J Med Virol. https://doi. org/10.1002/jmv.25731

19. Paules CI, Marston HD, Fauci AS (2020) Coronavirus infections - more than just the common cold. JAMA 323:707-708. https://doi.org/10.1001/jama.2020.0757

20. Wrapp D, Wang N, Corbett KS, Goldsmith JA, Hsieh C-L, Abiona O, Graham BS, McLellan JS (2020) Cryo-EM structure of the 2019-nCoV spike in the prefusion conformation. Science 367:1260-1263. https://doi.org/10.1126/science.abb2507

21. Villar J, Zhang H, Slutsky AS (2019) Lung repair and regeneration in ARDS: role of PECAM1 and Wnt signaling. Chest 155:587594. https://doi.org/10.1016/j.chest.2018.10.022

22. Channappanavar R, Perlman S (2017) Pathogenic human coronavirus infections: causes and consequences of cytokine storm and immunopathology. In: Semin Immunopathol, vol 5. Springer, pp 529-539. https://doi.org/10.1007/s00281-017-0629-x

23. Wang $\mathrm{H}, \mathrm{Ma} \mathrm{S}$ (2008) The cytokine storm and factors determining the sequence and severity of organ dysfunction in multiple organ dysfunction syndrome. Am J Emerg Med 26:711-715. https://doi. org/10.1016/j.ajem.2007.10.031

24. Chen N, Zhou M, Dong X, Qu J, Gong F, Han Y, Qiu Y, Wang J, Liu Y, Wei Y (2020) Epidemiological and clinical characteristics of 99 cases of 2019 novel coronavirus pneumonia in Wuhan, China: a descriptive study. Lancet 395:507-513. https://doi. org/10.1016/S0140-6736(20)30211-7

25. Diao B, Wang C, Tan Y, Chen X, Liu Y, Ning L, Chen L, Li M, Liu Y, Wang G (2020) Reduction and functional exhaustion of $T$ cells in patients with coronavirus disease 2019 (COVID-19). Front Immunol. https://doi.org/10.3389/fimmu.2020.00827

26. Kuba K, Imai Y, Rao S, Gao H, Guo F, Guan B, Huan Y, Yang P, Zhang Y, Deng W (2005) A crucial role of angiotensin converting enzyme 2 (ACE2) in SARS coronavirus-induced lung injury. Nat Med 11:875-879. https://doi.org/10.1038/nm1267

27. Raj VS, Mou H, Smits SL, Dekkers DH, Müller MA, Dijkman R, Muth D, Demmers JA, Zaki A, Fouchier RA (2013) Dipeptidyl peptidase 4 is a functional receptor for the emerging human coronavirus-EMC. Nature 495:251-254. https://doi.org/10.1038/ nature 12005

28. Lu C-w, Liu X-f, Jia Z-f (2020) 2019-nCoV transmission through the ocular surface must not be ignored. Lancet 395:e39. https:// doi.org/10.1016/S0140-6736(20)30313-5

29. Xia J, Tong J, Liu M, Shen Y, Guo D (2020) Evaluation of coronavirus in tears and conjunctival secretions of patients with SARSCoV-2 infection. J Med Virol. https://doi.org/10.1002/jmv.25725

30. Holshue ML, DeBolt C, Lindquist S, Lofy KH, Wiesman J, Bruce H, Spitters C, Ericson K, Wilkerson S, Tural A (2020) First case of 2019 novel coronavirus in the United States. N Engl J Med. https://doi.org/10.1056/NEJMoa2001191

31. Zhang H, Kang Z, Gong H, Xu D, Wang J, Li Z, Cui X, Xiao J, Meng T, Zhou W (2020) The digestive system is a potential route of 2019-nCov infection: a bioinformatics analysis based on single-cell transcriptomes. BioRxiv. https://doi. org/10.1101/2020.01.30.927806

32. Wang D, Hu B, Hu C, Zhu F, Liu X, Zhang J, Wang B, Xiang H, Cheng Z, Xiong Y (2020) Clinical characteristics of 138 hospitalized patients with 2019 novel coronavirus-infected pneumonia in Wuhan, China. JAMA. https://doi.org/10.1001/jama.2020.1585

33. Corman VM, Landt O, Kaiser M, Molenkamp R, Meijer A, Chu DK, Bleicker T, Brünink S, Schneider J, Schmidt ML (2020) Detection of 2019 novel coronavirus $(2019-\mathrm{nCoV})$ by real-time RT-PCR. Eurosurveillance. https://doi.org/10.2807/1560-7917. ES.2020.25.3.2000045

34. To KK-W, Tsang OT-Y, Yip CC-Y, Chan K-H, Wu T-C, Chan JM-C, Leung W-S, Chik TS-H, Choi CY-C, Kandamby DH (2020) Consistent detection of 2019 novel coronavirus in saliva. Clin Infect Dis. https://doi.org/10.1093/cid/ciaa149
35. Chang Z, Babiuk LA, Hu J (2007) Therapeutic and prophylactic potential of small interfering RNAs against severe acute respiratory syndrome. BioDrugs 21:9-15. https://doi.org/10.2165/00063 030-200721010-00002

36. Zorzitto J, Galligan CL, Ueng JJ, Fish EN (2006) Characterization of the antiviral effects of interferon- $\alpha$ against a SARS-like coronoavirus infection in vitro. Cell Res 16:220-229. https://doi. org/10.1038/sj.cr.7310030

37. Haagmans BL, Kuiken T, Martina BE, Fouchier RA, Rimmelzwaan GF, Van Amerongen G, van Riel D, De Jong T, Itamura S, Chan K-H (2004) Pegylated interferon- $\alpha$ protects type 1 pneumocytes against SARS coronavirus infection in macaques. Nat Med 10:290-293. https://doi.org/10.1038/nm1001

38. Loutfy MR, Blatt LM, Siminovitch KA, Ward S, Wolff B, Lho H, Pham DH, Deif H, LaMere EA, Chang M (2003) Interferon alfacon-1 plus corticosteroids in severe acute respiratory syndrome: a preliminary study. JAMA 290:3222-3228. https://doi. org/10.1001/jama.290.24.3222

39. Pulido F, Arribas JR, Delgado R, Cabrero E, González-García J, Pérez-Elias MJ, Arranz A, Portilla J, Pasquau J, Iribarren JA (2008) Lopinavir-ritonavir monotherapy versus lopinavir-ritonavir and two nucleosides for maintenance therapy of HIV. AIDS 22:F1-F9. https://doi.org/10.1097/QAD.0b013e3282f4243b

40. Lin S, Shen R, Guo X (2020) Molecular modeling evaluation of the binding abilities of Ritonavir and Lopinavir to Wuhan pneumonia Coronavirus proteases. BioRxiv. https://doi. org/10.1101/2020.01.31.929695

41. Savarino A, Di Trani L, Donatelli I, Cauda R, Cassone A (2006) New insights into the antiviral effects of chloroquine. Lancet Infect Dis 6:67-69. https://doi.org/10.1016/S1473-3099(06)70361 $-9$

42. Yan Y, Zou Z, Sun Y, Li X, Xu K-F, Wei Y, Jin N, Jiang C (2013) Anti-malaria drug chloroquine is highly effective in treating avian influenza A H5N1 virus infection in an animal model. Cell Res 23:300-302. https://doi.org/10.1038/cr.2012.165

43. Zhang J, Zhou L, Yang Y, Peng W, Wang W, Chen X (2020) Therapeutic and triage strategies for 2019 novel coronavirus disease in fever clinics. Lancet Respir Med 8:e11-e12. https://doi. org/10.1016/S2213-2600(20)30071-0

44. Biot C, Daher W, Chavain N, Fandeur T, Khalife J, Dive D, De Clercq E (2006) Design and synthesis of hydroxyferroquine derivatives with antimalarial and antiviral activities. J Med Chem 49:2845-2849. https://doi.org/10.1021/jm0601856

45. Yao X, Ye F, Zhang M, Cui C, Huang B, Niu P, Liu X, Zhao L, Dong E, Song C (2020) In vitro antiviral activity and projection of optimized dosing design of hydroxychloroquine for the treatment of severe acute respiratory syndrome coronavirus 2 (SARSCoV-2). Clin Infect Dis. https://doi.org/10.1093/cid/ciaa237

46. Blaising J, Polyak SJ, Pécheur E-I (2014) Arbidol as a broadspectrum antiviral: an update. Antiviral Res 107:84-94. https:// doi.org/10.1016/j.antiviral.2014.04.006

47. Cao Y-c, Deng Q-x, Dai S-x (2020) Remdesivir for severe acute respiratory syndrome coronavirus 2 causing COVID-19: an evaluation of the evidence. Travel Med Infect Dis. https://doi. org/10.1016/j.tmaid.2020.101647

48. Duan Y, Zhu H-L, Zhou C (2020) Advance of promising targets and agents against 2019-nCoV in China. Drug Discov Today. https ://doi.org/10.1016/j.drudis.2020.02.011

49. Lythgoe M, Middleton P (2020) Ongoing clinical trials for the management of the COVID-19 pandemic. Trends Pharmacol Sci. https://doi.org/10.1016/j.tips.2020.03.006

50. Arabi YM, Mandourah Y, Al-Hameed F, Sindi AA, Almekhlafi GA, Hussein MA, Jose J, Pinto R, Al-Omari A, Kharaba A (2018) Corticosteroid therapy for critically ill patients with Middle East respiratory syndrome. Am J Respir Crit Care Med 197:757-767. https://doi.org/10.1164/rccm.201706-1172OC 
51. Huang L, Liu Y, Luo R, Zeng L, Telegina I, Vlassov VV, Zhang L (2017) Arbidol for preventing and treating influenza in adults and children. Cochrane Database Syst Rev. https://doi.org/10.3390/ molecules 25071577

52. Chen F, Chan K, Jiang Y, Kao R, Lu H, Fan K, Cheng V, Tsui W, Hung I, Lee T (2004) In vitro susceptibility of 10 clinical isolates of SARS coronavirus to selected antiviral compounds. J Clin Virol 31:69-75. https://doi.org/10.1016/j.jcv.2004.03.003

53. Hammer Q, Rückert T, Romagnani C (2018) Natural killer cell specificity for viral infections. Nat Immunol 19:800-808. https:// doi.org/10.1038/s41590-018-0163-6

54. Arase H, Mocarski ES, Campbell AE, Hill AB, Lanier LL (2002) Direct recognition of cytomegalovirus by activating and inhibitory NK cell receptors. Science 296:1323-1326. https://doi. org/10.1126/science. 1070884

55. Spanholtz J, Tordoir M, Eissens D, Preijers F, van der Meer A, Joosten I, Schaap N, de Witte TM, Dolstra H (2010) High logscale expansion of functional human natural killer cells from umbilical cord blood CD34-positive cells for adoptive cancer immunotherapy. PLoS ONE. https://doi.org/10.1371/journ al.pone.0009221

56. Matthay MA, Goolaerts A, Howard JP, Lee JW (2010) Mesenchymal stem cells for acute lung injury: preclinical evidence. Crit Care Med 38:S569. https://doi.org/10.1097/CCM.0b013e3181 f1ff1d

57. Moodley Y, Atienza D, Manuelpillai U, Samuel CS, Tchongue J, Ilancheran S, Boyd R, Trounson A (2009) Human umbilical cord mesenchymal stem cells reduce fibrosis of bleomycin-induced lung injury. Am J Pathol 175:303-313. https://doi.org/10.2353/ ajpath.2009.080629

58. Van Griensven J, Edwards T, de Lamballerie X, Semple MG, Gallian P, Baize S, Horby PW, Raoul H, Magassouba NF, Antierens A (2016) Evaluation of convalescent plasma for Ebola virus disease in Guinea. N Engl J Med 374:33-42. https://doi.org/10.1056/ NEJMoa1511812

59. Cheng Y, Wong R, Soo Y, Wong W, Lee C, Ng M, Chan P, Wong $\mathrm{K}$, Leung C, Cheng G (2005) Use of convalescent plasma therapy in SARS patients in Hong Kong. Eur J Clin Microbiol Infect Dis 24:44-46. https://doi.org/10.1007/s10096-004-1271-9

60. Traggiai E, Becker S, Subbarao K, Kolesnikova L, Uematsu Y, Gismondo MR, Murphy BR, Rappuoli R, Lanzavecchia A (2004) An efficient method to make human monoclonal antibodies from memory B cells: potent neutralization of SARS coronavirus. Nat Med 10:871-875. https://doi.org/10.1038/nm1080

61. Wong SK, Li W, Moore MJ, Choe H, Farzan M (2004) A 193amino acid fragment of the SARS coronavirus S protein efficiently binds angiotensin-converting enzyme 2. J Biol Chem 279:31973201. https://doi.org/10.1074/jbc.C300520200

62. Tian X, Li C, Huang A, Xia S, Lu S, Shi Z, Lu L, Jiang S, Yang Z, Wu Y (2020) Potent binding of 2019 novel coronavirus spike protein by a SARS coronavirus-specific human monoclonal antibody. Emerg Microbes Infect 9:382-385. https://doi.org/10.1080/22221 751.2020.1729069
63. Nagle V, Gaikwad M, Pawar Y, Dasgupta S (2020) Marine Red Alga Porphyridium sp. as a source of sulfated polysaccharides (SPs) for combating against COVID-19 (Preprints)

64. GuhaRay A, Guoxiong M, Sarkar A, Bordoloi S, Garg A, Pattanayak S (2019) Geotechnical and chemical characterization of expansive clayey soil amended by biochar derived from invasive weed species Prosopis juliflora. Innov Infrastruct Solut 4:44. https ://doi.org/10.1007/s41062-019-0231-2

65. Singh R, Adhikari R (2020) Age-structured impact of social distancing on the COVID-19 epidemic in India. arXiv preprint

66. Das I, Das S, Chakraborty I, Ghangrekar M (2019) Bio-refractory pollutant removal using microbial electrochemical technologies: a short review. J Indian Chem Soc 96:493-497

67. von Maubeuge KP (2018) Geosynthetic barriers in regulations and recommendations in line with the ISO design guide? Innov Infrastruct Solut 3:75. https://doi.org/10.1007/s41062-018-0177-9

68. Phale PS, Sharma A, Gautam K (2019) Microbial degradation of xenobiotics like aromatic pollutants from the terrestrial environments. In: Pharmaceuticals and personal care products: waste management and treatment technology. Elsevier, pp 259-278. https://doi.org/10.1016/B978-0-12-816189-0.00011-1

69. Mallapaty S (2020) How sewage could reveal true scale of coronavirus outbreak. Nature 580:176-177. https://doi.org/10.1038/ d41586-020-00973-x

70. Gundy PM, Gerba CP, Pepper IL (2009) Survival of coronaviruses in water and wastewater. Food Environ Virol 1:10. https://doi. org/10.1007/s12560-008-9001-6

71. Wang X, Li J, Guo T, Zhen B, Kong Q, Yi B, Li Z, Song N, Jin M, Xiao W (2005) Concentration and detection of SARS coronavirus in sewage from Xiao Tang Shan Hospital and the 309th Hospital of the Chinese People's Liberation Army. Water Sci Technol 52:213-221. https://doi.org/10.2166/wst.2005.0266

72. van Doremalen N, Bushmaker T, Morris DH, Holbrook MG, Gamble A, Williamson BN, Tamin A, Harcourt JL, Thornburg NJ, Gerber SI (2020) Aerosol and surface stability of SARSCoV-2 as compared with SARS-CoV-1. N Engl J Med. https:// doi.org/10.1056/NEJMc2004973

73. Gong B, Zhang S, Yuan L, Chen KZ (2020) A balance act: minimizing economic loss while controlling novel coronavirus pneumonia. J Chin Gov. https://doi.org/10.1080/23812346.2020.17419 40

74. Goyal K, Chauhan P, Chhikara K, Gupta P, Singh MP (2020) Fear of COVID 2019: first suicidal case in India. Asian J Psychiatry 49:e101989-e101989. https://doi.org/10.1016/j.ajp.2020.101989

75. Viner RM, Russell SJ, Croker H, Packer J, Ward J, Stansfield C, Mytton O, Bonell C, Booy R (2020) School closure and management practices during coronavirus outbreaks including COVID19: a rapid systematic review. Lancet Child Adolesc Health. https ://doi.org/10.1016/S2352-4642(20)30095-X

76. Cadotte M (2020) Early evidence that COVID-19 government policies reduce urban air pollution. EarthArXiv. https://doi. org/10.31223/osf.io/nhgj3 